\title{
Challenges Influencing Peace Building Strategies in Somalia: A Study of AU Mission in Somalia (AMISOM)
}

\author{
William Oluoch Ligawa \\ Department of Peace and Conflict Studies, Masinde Muliro University of Science and Technology, Kakamega, Kenya \\ Email: ligwawilson@gmail.com
}

How to cite this paper: Ligawa, W.O. (2017) Challenges Influencing Peace Building Strategies in Somalia: A Study of AU Mission in Somalia (AMISOM). Open Access Library Journal, 4: e3249.

https://doi.org/10.4236/oalib.1103249

Received: November 21, 2016

Accepted: October 16, 2017

Published: October 19, 2017

Copyright (c) 2017 by author and Open Access Library Inc.

This work is licensed under the Creative Commons Attribution International License (CC BY 4.0).

http://creativecommons.org/licenses/by/4.0/

\section{(c) (i) Open Access}

\begin{abstract}
Somalia has been caught in a wave of violent conflicts since collapse of the central government in the early 1990s. Different armed militant groups have been controlling most parts of the failed state. Al shabaab remains a major threat to the weak Federal Government of Somalia. Different peace support operations have been mounted in the past yet durable peace remains elusive. Previous peace support operations were faced with a lot of challenges prompting UN and the international community to abort the interventions. UNOSOM I and II failed to meet their mandates with the former ending after an outcry by the American citizens for US to withdraw its forces out of Somalia due to heavy casualty that was incurred by the marine forces. The Special Forces suffered fatalities during the mission dubbed Gothic the Serpent which was aimed at capturing the notorious warlord General Farah in the murky streets of Mogadishu. Such failures of the past peace support operations are still mirrored with the AMISOM. In this regard, this article evaluated the challenges AMISOM faces in influencing peace building strategies in Somalia. The researcher targeted the AMISOM troops and the locals. The primary data was collected through interviews and questionnaires. Secondary data was gathered and reviewed from journals, books, magazines, newspapers and published proceedings that corroborated the primary data. The study found out that the mechanism lacks appropriate systems for intelligence and information gathering, the AMISOM is poorly equipped with lack of sustainable funding sources and weak Federal Government of Somalia complicates the peace support operations since it is marred with internal wrangles. The study recommends that alternative sustainable sources of fund to be established; and AMISOM should enhance capacity building for the National Security Agencies (Somalia National Army, Police Force and National Intelligence Service Agency) as part of exit strategy. The findings should help in designing peace support operation practices, processes
\end{abstract}


and strategies for ensuring durable and sustainable peace in Somalia and other war torn states.

\section{Subject Areas}

Politics

\section{Keywords}

Violent Conflict, AMISOM, Peace Support Operations, Al Shabaab

\section{Introduction}

Somalia has been involved in a vicious conflict since the collapse of central government in the early 1990s. Various peace support operations have been conducted in Somalia previously. Humanitarian crises and risk faced by the vulnerable populations from the predating warlords prompted the UN and the international community to intervene. In the past such missions have been United Nations Operation in Somalia (UNOSOM), Intergovernmental Authority on Development in Somalia dubbed as IGASOM and currently African Mission in Somalia (AMISOM). Pacification of Somalia has been carried out under the umbrella of these missions. However, durable peace still remains elusive.

Somalia's war spillover effects are already being felt in the neighbouring countries. Conflict has ravaged the country since early 1991 with the collapse of the Said Barre's regime (former president of Somalia before its collapse). Wanton destruction of property and human cost of this vicious conflict remains one of the worst conflicts of the century. UN Security Council passed a resolution for deployment of AU troops for peace support operations. The first AMISOM contingent from Uganda arrived in 2007. Presently, there are four more contingents from different nationalities: Kenya, Djibouti, Burundi and Ethiopia. Security situation remains fragile despite the presence of "Green-helmets" on the ground. There have been a series of suicide bomb attacks in Mogadishu with the most recent one at a five star hotel leading to fatalities. Al shabaab has been able to conduct successful operations against these troops. They have been able to overrun their military camps forcing the AMISOM troops to collapse and abandon their defensive positions. This includes the recent $\mathrm{Al}$ shabaab attack on Kenya Defence Forces' (KDF) base in El Ade which led to the deaths of around 63 soldiers. Consequently, the terror group has been able to seize some of the tightly held towns and centres from the troops. The armed militia group is gaining momentum against the troops' combined efforts to pacify Somalia and degrade their ( $\mathrm{Al}$ shabaab) capability. Peace support operations have not been able to achieve their mandates and as a result, durable peace remains elusive in most parts of the host countries.

The immediate cause of conflict in Somalia was related to crises in governance. The democratic principles were being enacted at the top level while ne- 
potism, corruption and clan competition were rapidly eroding the underpinnings of Somalia's nascent democratic system. The Political misrule, combined with pervasive corruption, hampered the maturity of administrative institutions and undermined development of the country's embryonic social services network, thereby engendering general disillusionment with the entire system [1]. The exploitation of clan identity by political opportunists swiftly gave rise to an unwieldy number of clan based political parties [2].

Since the arrival of African Union forces in Somalia their main enemy has been Al-Shabaab. Originally the militia for the Union of Islamic Courts (UIC), Al-Shabaab has now morphed into a force of its own whose leaders have variously called for: a "Greater Somalia" incorporating into Somalia parts of Ethiopia, Kenya and Djibouti where large numbers of ethnic Somalis reside; pledged allegiance to Al-Qaeda; endorsed global jihad [3]; and praised terrorist attacks both inside Somalia and beyond. A partial list of some of Al-Shabaab's more high-profile terror attacks includes: coordinated suicide-bombings in Hargeisa, Somaliland and Bosaso, Puntland in October 2008; at least 40 were killed, the targets being local government offices, a UN compound and the Ethiopian consulate [4]; a suicide-bombing of a university graduation ceremony in Mogadishu in December 2009; at least 19 were killed, the targets being Somali Transitional Federal Government officials in attendance of the ceremony [5] and suicide bombing of Hotel in September 2015 in Mogadishu killing scores of Jazeera Palace hotel residents [6].

The recent developments show that the AMISOM troops are getting overwhelmed by the Al shabaab. The defensive positions of some troops have been overrun by the terror group. Ugandan combat team stationed in Janaale suffered heavy casualty. At least 50 soldiers were killed and another 50 are still missing in action [7]. In the same month, both Burundian and Ugandan forces were also overrun resulting into scores of deaths on the AMISOM's side. The Kenya Defence Forces' (KDF) defended locality at El Ade in Gedo region was breached by the armed militia group. There were 63 fatalities and scores of soldiers being injured. It seems the AMISOM could not do immediate evacuation resulting into more deaths.

Al shabaab recaptured three towns under the watch of AMISOM's troops. These towns include: Bugda, El Salundi and Kuntuwarey. Troops in whichever kind of warfare, are supposed to hold the ground (towns, centres and cities) captured from the enemy. They are not supposed to cede any inch of the captured ground. Soldiers only abandon the towns captured when they lack the capacity to hold it anymore. From those increased enemy activities in Somalia, it seems that the troops are not able to effectively conduct peace support operations. This present study thus focuses on why the assurance of AMISOM troops on peace and security in Somalia remains uncertain.

\subsection{The Mandate}

The AMISOM has various mandates to undertake. These mandates need various 
supports so that they can be achieved. Milestones to be accomplished by the troops can't just happen; the troops as well as the other stakeholders need to play their respective roles. AMISOM, as a multidimensional PSO, is mandated to: take all necessary measures, as appropriate, and in coordination with the Somalia National Defence and Public Safety Institutions, to reduce the threat posed by $\mathrm{Al}$ shabaab and other armed opposition groups; Assist in consolidating and expanding the control of the FGS over its national territory; assist the FGS in establishing conditions for effective and legitimate governance across Somalia, through supports as appropriate, in the areas of security, including the protection of Somali institutions and key infrastructure, governance, rule of law and delivery of basic services; provide, within its capabilities and as appropriate, technical and other support for the enhancement of the capacity of the Somalia State institutions, particularly the National Defence, Public Safety and Public Service Institutions; support the FGS in establishing the required institutions and conducive conditions for the conduct of free, fair and transparent elections by 2016, in accordance with the Provisional Constitution; liaise with humanitarian actors and facilitate, as may be required and within its capabilities, humanitarian assistance in Somalia, as well as the resettlement of internally displaced persons and the return of refugees; facilitate coordinated support by relevant $\mathrm{AU}$ institutions and structures towards the stabilization and reconstruction of Somalia, and provide protection to $\mathrm{AU}$ and $\mathrm{UN}$ personnel, installations and equipment, including the right of self-defence. As required by the theory of securitization, support of the mandate remains key $\mathrm{n}$ the successful facilitation of peace strategies in Somalia.

The mandates should be able to bring the Horn of Africa back to its former self. The delivery of basic services, effective governance, rule of law, protection of Somali institutions and the establishment of Somalia National Defence are key items that should be quickly put into place by the AMISOM. Posture adopted by AMISOM presently can only guarantee limited success. A lot needs to be done yet the means is quite limited. These sentiment augurs with $75 \%$ of the respondents who agree to the fact that peace support operation does not receive the support that will make it realize meaningful gains.

When the UN Security Council adopted Resolution 1772 in 2007 it authorized AMISOM to take "all necessary measures" to inter alia protect the institutions of the Transitional Institutions of the Somali government and "support dialogue and reconciliation" by providing protection and safe passage to personnel involved. In Resolution 2036 of 2012 the Security Council was more specific in authorising AMISOM "to reduce the threat posed by Al shabaab and other armed opposition groups in order to establish conditions for effective and legitimate governance across Somalia”. Despite the political objectives, AMISOM's role, circumscribed by the overall scope and direction of the Security Council, was originally primarily seen as a military contribution, aimed at creating an enabling security environment, and part of a wider political strategy that is still taking shape. An informant enlightened, "support of the mandate remains a big chal- 
lenge for the success of peace support operations. This is a multicultural undertaking that needs support of various kinds. The soldiers doing their work cannot achieve much as defined by the mandate if they are not facilitated in the quest to accomplish their missions. The AU through AMISOM should provide the infrastructure required to facilitate these mandates".

AMISOM mandate is renewed every year and is subject to political dynamics, financial and other factors out of control of the AU and the Somali government. At the moment, AMISOM faces a lot of financial crisis especially after EU announced a cut in their donor aid by $20 \%$ (Informant). AU has to think on its feet on how to generate funds to keep the operations going. There are a lot of negotiations that take place between African decision-makers, Somali government and their non-African partners. The outcome of these negotiations has complex motives and interests that have consequences on the autonomy of the mission. The TCCs should rotate their soldiers to avoid mission creep. They should not be allowed to say for more than a year as this leads to laxity.

\subsection{Uncertain Political Situation in Somalia}

The political power in Somalia can be characterized as local, fragmented, violent, heterogenic and based on hybrid structures of formal and informal institutions controlled by clans or militias, in which different socio-political orders interact. This fluidity of structure, with access to resources and power being an important source of clan conflicts, has been an enduring challenge for peace negotiations and will continue doing so.

Looking beyond the clan issue, there are disagreements about the nature, or even desirability of the state. Much of Somali society has traditionally been nomadic and suspicious of the interference of a central authority in their affairs, a sentiment reinforced by experience with military dictatorship. The major clans favour a federal system of governance where distinct units of the country are largely autonomous but federated into a loose nation state, thus giving them control over their own territories.

The success of AMISOM is therefore partially dependent on whether centralised structures of government can demonstrate legitimacy among the Somali citizenry. One way of demonstrating legitimacy is ensuring the timely and efficient delivery of the much-needed public goods and services and providing stability and peace throughout the liberated areas. The challenge with the recognition of legitimacy is already manifest in the country with accusations that the local leaders who have replaced former Al-Shabaab leaders do not, often, come from the majority clans in their areas but are puppets of the central authority. To date, the central government continues to struggle to gain the needed legitimacy (Respondent).

\subsection{Intelligence and Information Gathering}

Intelligence is produced to influence government action. The ultimate purpose of intelligence is to provide information that helps decision-makers make better 
policy choices. Military operations are supposed to intelligence driven. Spates of deadly offensive by the $\mathrm{Al}$ shabaab militants on the AMISOM bases leave many wondering if there is any intelligence on the ground. One respondent who was a survivor from one of the ill-fated base noted that, they only get general information which is disjointed and thus acting on such piece becomes hard. The soldiers are supposed to stay alert but the level of alertness increases too with the level of threat they are anticipating. Too much confusing information trickles in, the soldiers tend to take it as routine which in long term becomes too dangerous because the enemy is likely to catch them flat footed. Most of the exercises are done blindly like patrols, scouting and general road movements. This has resulted into several deaths from enemy action. Such deaths would have been prevented.

The AMISOM leadership should establish strong domestic intelligence to deal with threats emanating from the terror group. Threats from transnational terrorism know no boundary. Problems such as terrorism and organized crime cannot be adequately dealt with using domestically acquired intelligence only. Intelligence about these threats must also be gathered outside our own borders. Furthermore, tackling the threats Somalia now faces, such as an allegedly new type of terrorism, requires human intelligence; signals intelligence alone can no longer meet the requirement. The long civil war in Horn of Africa has made a brooding ground for even foreign fighters. Al shabaab has affiliations with Al-Qaeda and links with Boko haram too.

On Somalia, [8] recounts how, after 9/11, the CIA recruited local militia groups to capture and kill "Islamists". That term defined a far wider range of ideologies than al Qaida's, which at the time had only a handful of active supporters in the country. Each week, CIA agents flew in by private jet from Nairobi to provide the roaming death squads with their target lists and dollar-filled briefcases. In 2006, an uprising in response to these CIA proxies led to the Islamic Courts Union coming to power in Mogadishu. The Bush administration interpreted the Courts as another "Islamist" threat and decided a full-scale military invasion was needed. On this occasion, the job was outsourced to the Ethiopian army-supported with US airpower and special operations forces on the ground. The violence of the Ethiopian invasion, in turn, pushed $\mathrm{Al}$ shabaab, the marginal youth wing of the Courts, to the fore as the main organiser of Somali resistance. For the first time, a group with a Taliban-style agenda began to control territory in Somalia, an outcome that owed much to US policies ostensibly intended to forestall such a possibility. In Somalia, the local intelligence agency is paid for by the CIA and its operations were kept secret from the Somali Government ministers.

The policy of extra-judicial killings in Pakistan, Yemen and Somalia-usually carried out by drone strike-take place far from Iraq and Afghanistan, where the US is officially at war, and therefore lack any plausible legitimacy under conventional laws of warfare that allow for the killing of combatants on a battlefield. Legally, killing a "high-value target" (HVT) was often easier than imprisoning him 
and the technology of bombing by remote control made possible an alternative to the complex politics of detaining suspects.

The militants' commanders operate within the Somalia. Movements are done under the cover of darkness knowing very well that they are high value targets for the AMISOM troops. At the time of writing, within the sector 2, they have intensified their operations. The armed group seemed to have perfected their tactics with time and AMISOM has to work round the clock to beat them. One of the informants narrated that the strategy adopted by the AMISOM in fighting the militia is counterproductive in the long run. Their key leaders are targeted then killed. Sometimes, they seek help from the US soldiers since they have sophisticated surveillance equipment. The armed militia has never suffered from leadership vacuum. If there is always one ready to take up the leadership role and it becomes cyclic. They would have adopted other means probably dialogue. The announcement followed revelations by the Kenyan military that it killed Al-Shabaab senior commander in charge of intelligence, Mohammed Karatey alias Mahat Karatey. Karatey is said to have been killed in an airstrike earlier this week and was suspected to have been a key player in the attack on a Kenya Defence Forces camp in El Adde on January 15. The alamnyat, $\mathrm{Al}$ shabaab's intelligence wing has suicide bombers, assassins, explosive experts and information gatherers. The killing of the commander is a big blow to the terror group. The wing provides logistics and operations support throughout the Horn of Africa. Karate was the second senior most commander to be killed after Abdi Dek, the operations commander of Zebeir brigade. It is glaring that every time a leader is killed, there is always someone ready to take over the remnants of leadership.

The intelligence and information gathering mechanisms have not been developed. The intelligence is supposed to be collaborated amongst the contingents. The gap is being exploited by the $\mathrm{Al}$ shabaab. Every country works disjointedly. The information gathered is shared so that the flanking friendly forces are aware of one other's operation. Failure to that works at the disadvantage of the whole mission. The unity of effort has to be realized by the participating troop contributing countries.

Need of equipment which should find, acquire and fix the enemy. For Signal intelligence, machines like jammers and interceptors are needed. Other equipment can be used to tap into the $\mathrm{Al}$ shabaab leadership communications. AMISOM is yet to embrace electronic warfare which is essential in the fight against terrorism. The militant has fluid tactics that remain unpredictable. In war against insurgency, the force needs to be ahead of the enemy. The target acquisition assets are fundamental to this end. When the enemy's activity is spotted at a particular place, then priority should be located so that the air assets are deployed there. Degrading Al shabaab's capability is going to be a daunting task for the forces.

Human intelligence (Humint) is paramount in the information gathering. Given that this is a coin operation and such operations are usually carried out amongst the locals, humint is necessary as it complements other methods of in- 
formation collection. However, such sources have to be maintained by money. The intelligence officers lack funds to maintain their sources. This is crucial for winning loyalty of source. Humint can be utilised in the fight against any terror group. They should endeavor to identify and use of locals in humint. Further, efforts should be made to implant informers within the terror groups. Real time intelligence is key in fighting irregular warfare. Intelligence mechanism should be able to infiltrate the ranks of $\mathrm{Al}$ shabaab. This will ensure constant supply of enemy intelligence. AMISOM is yet to exhaust such tactic. Intelligence is necessary if the commander is to make any decision to shape any operation. The dynamic and cyclic process is altered throughout the operation depending on the commander's intelligence requirements. The collection plan of AMISOM should be comprehensive if they are to defeat the insurgent group.

There is little or lack of liaison between agencies. The intelligence mechanisms have not developed the matrix for liaison purposes. The NGOs and other friends of AMISOM should be collaborated with so that they share any intelligence with the AMISOM's intelligence cell. The Force Headquarters should have well trained personnel to handle the intelligence docket. The collection plan should be laid out. The contingents lack contact points. The various intelligence officers from various contingents should have liaison or contact points when they need to share any piece of tactical information.

\subsection{Poorly Equipped Personnel}

AMISOM consistently struggles to marshal the requisite military personnel and range of military assets needed for complex peace operations. Among the assets in highest demand in difficult the theatres of the region such as Sudan and Somalia are helicopters, i.e. utility and attack helis, armored personnel carriers, communications and intelligence equipment, unmanned aerial vehicles, night vision goggles, and, in the case of troops in Mogadishu, battle tanks. Troops also lack sophisticated mortar radar system, which could have helped it reduce levels of civilian casualties [9]. Without these equipments, despite the level of training of the soldiers, they cannot beat the contemporary insurgency. The modern militia groups are more equipped than even some national armies. Troops should not be taken to a theatre of war with no adequate military hardware. The defeat could be eminent causing more complications to already a complex humanitarian situation.

In the absence of the necessary capabilities, such an approach brings a high level of risk, not only of failure but also of raising people's expectations that cannot be fulfilled. Worse still, it undermines the credibility of peace support operations and weakens the organization that is responsible. As for military personnel, the troop's greatest deficits are specialists with niche skills including medicine, engineering, and intelligence gathering. To fill these gaps, the mechanism relies on external donors (the friends of AMISOM) to provide funding, training, and equipment directly to troop contributing countries-hence bypassing the normal chain. 
The Al shabaab militant is still strong and it controls most of the countryside. Their morale in the recent past is quite high after successful attacks on some AMISOM bases. They retain the capacity of launching deadly and large scale attacks on the troops and even in the neighbouring countries like Kenya. In the theory of securitization, the act of securing the objects calls for the resources. The availability of these resources influences the success or failure of the securitization process. It is saddening for the troops to lose soldiers due to lack of equipment. AU had previously approved 12 helicopters to be brought to the theatre; however, up to now none has been brought. The casualty on AMISOM troops seem to be rising. With latest attack on Kenyan contingent at the army base in El-Ade. The offensive resulted to into many deaths. The Kenyan government said that she lost 63 soldiers in the attack whereas the Mogadishu government puts the figure at about 200 soldiers. According to SIPRI, 2015, 1039 AMISOM soldiers were killed in action between January 1, 2009, and December 31, 2013, with an additional 69 fatalities in 2014 (per AMISOM) bringing the total to 1108 dead from 2009 through 2014. The number could be much higher at the time of writing.

Attack helicopters and drones are necessary for this mission. Al shabaab has revolutionized their fighting tactics. Their modes of attack have changed with time. Djibouti affirmed the critical importance of enhanced support to AMISOM and specifically reiterates the need for the generation and deployment of operational enablers and force multipliers, including pledged helicopters from Ethiopia, Kenya and Uganda and, therefore requests the UN to expedite the finalisation of Letters of Assist in order to allow for their deployment as Mission assets, taking due consideration of the high-intensity nature of AMISOM operations. In addition, the AU Commission should report back to the Summit on the progress made in the authorisation and deployment of these Mission assets, not later than 30 days from the adoption of this Declaration. Commends all TCCs and other AU Member States for their various contributions to AMISOM operations and encourages other international partners to contribute and deploy air assets in order to facilitate AMISOM operations [10]. Since overrunning some AMISOM bases, they have enough ammunition to carry out decisive offensive on tightly held AMISOM bases and strategic towns like Mogadishu. The situation is further aggravated by the fact that they have enough ordinances to make large amounts of IEDs.

The AMISOM leadership must rethink their strategy of fighting these militants. Aerial surveillance is easily carried out by the armed helicopters. They double up as aerial observation posts. This will minimize fatalities and casualties on the side of AMISOM. The aircrafts which were to be provided by the AMISOM are yet to reach the theatre. Soldiers leaving out for patrols do so blindly. Drones are not beyond reach. The troops can use them for reconnaissance purposes. A fighting patrol should be well equipped to fight on its own before reinforcement by other troops. Troops are sent out without right weapons and to worse on a foot patrol thus making sitting ducks for the well armed $\mathrm{Al}$ 
shabaab. Unchecked deaths of the interveners will persuade troop contributing countries from sending their soldiers to the war-raged country. In the future, finding troops for peace enforcement might become hard. One informant who is a survivor on one of the overrun bases recounted that AMISOM was not able to send them rescue team. They fought on their own until they were overwhelmed by the Al shabaab. It was a fierce battle and the insurgent group came in droves with heavy machine guns. They efforts to repulse the enemy did not yield any fruit. The SVBIED exploded inside the defensive position wrecking havoc in the area. Quick Reaction Force ( $Q R F)$ came nearly on the fifth day yet they were other AMISOM bases nearby. It baffles if casualty evacuation reaches on the fifth. Most of the soldiers died of battle wounds which could have been managed had the rescue reached on the same day. Fighting trenches should be properly constructed rather than being squalidly made. Such is the tragedy which is bedeviling the troops. Maintain a force in reserve for contingency reasons seem not to have been factored by the mission. Any peace support operations should have foresight on reinforcement's plan. Each sector based on size should have a quick reaction force of at least a battalion strong. The battalion should remain uncommitted ready for deployment on reinforcement at the shortest notice possible.

Utility aircrafts are long overdue. Facilitation of movements of troops from one theatre of war to another becomes easy. Whether is it strategic or operational airlift, it saves man-hours and soldiers reach required destination while still fresh. C 130 Hercules is the best aircraft for transport. Resupply and replenishment of fresh foods is done by road. Soldiers lose their lives and get permanent injuries from IED attacks. One respondent suggested that AMISOM should have aircrafts for transporting troops and foodstuffs. Unnecessary casualties could be avoided through procurements of such. Utility helicopters are suited for these movements. Armed air reconnaissance can be conducted by these attack helicopters. Somali is vast and large acreage is still under control of $\mathrm{Al}$ shabaab. Intensive air patrols would take care of these places.

AMISOM lack maritime component. And Somalia's more than $3300 \mathrm{~km}$ coastline remains unpatrolled. Unpatrolled coastline has seen influx of illegal fire arms. These weapons end in the arms of the militant group. They clandestinely import fire arms through the unpatrolled waters. It has had a lot of pirates' activities. As the end of the first decade of the $21^{\text {st }}$ century fast approaches, it can rightly be asserted that transnational security challenges and threats have arguably dominated, shaped, influenced and adversely affected the stability of the global political landscape, particularly on the African continent [11]. New threats cannot be readily defeated by the traditional defences that states have erected to protect their territories and their citizenry. The geopolitical landscape has been altered radically and few of today's dangers have the character of overt military aggression, stemming from a clearly defined sovereign source.

The dumping of these wastes in the sea across Somalia became a multi-billion dollar enterprise as the dumping cost was only $\$ 2.50$ per ton in Africa compared 
to $\$ 250$ per ton in Europe [12]. Moreover, the European ships which dumped the wastes along the coasts of Somalia and returned home laden with illicit catches of fish proved to be far more devastating to the Somalis. Some Somalis argue that fishermen became pirates as their life and livelihood was being destroyed while the foreign governments chose to ignore these issues. Somalia which is one of the richest fishing grounds in the world and like all other maritime countries has legal rights over an Exclusive Economic Zone (EEZ) of 200 nautical miles has no Navy to enforce its control and the poor fishermen in the region simply do not have the resources to compete with the big ships of the foreigners. Even though Somalia owned the fisheries and minerals in the area they were being utilised by other countries. Thus, the angry fishermen of Somalia, left with no other choice, began to patrol the coastal areas considering themselves to be the authorised coastguards. Commenting on the piracy emerging from Somalia, Peter Lehr remarked-It's almost like a resource swap; Somalis collect up to $\$ 100$ million a year from pirate ransoms off their coasts. And the Europeans and Asians poach around $\$ 300$ million a year in fish from Somalia water [13].

In the equipment reimbursement package, AMISOM should struggle to ensure that country owned equipment (COE) is serviceable to the required standard percentages. If that is not achievable, then AU owned equipment should be provided. AU should do a thorough equipment inspection and provide equipment they feel is crucial to the troops, if they cannot be secured by the TCC. As noted by one informant, one of the TCC had a serviceability status of equipment at $40 \%$ then how does one launch an offensive against the armed militia with such unserviceable equipment. Modern equipment should be obtained by AMISOM so that soldiers are able to carry out their mandate. Protection of key government installations and civilians require specialized equipment. The mission is operating under article 51 of the UN charter thus sustained minimum use of firepower is unavoidable. Mortar detecting radars are yet to be secured by the mission.

\subsection{Training}

It should be acknowledged that the training for peacekeeping and peace enforcement differs, PSOs require training in the form of mine or booby-trap handling, patrolling, checkpoint operations, media liaison, supervision of cease-fires, maintenance of law and order and the rebuilding of infrastructure, which is especially important in Africa. Peace enforcement, on the other hand, involves enforcement of AU sanctions, protection of minority rights, humanitarian relief efforts, separation and disarming of warring factions and the restoration of law and order. AMISOM training is mission-specific and makes provision for complex, integrated, multifaceted operations aimed at supporting and facilitating comprehensive peace agreements. In addition, the focus of peace operations is shifting gradually from peacekeeping to peace-building.

The training of the military and the police force should be geared towards allowing the government security to be police-led rather than military-led. This is essentially not taking place. The national security should be cohesive and legiti- 
mate in nature. The unity is hard to achieve due to disparaging clan subtleties. There is political in-fighting that is hindering the progress of AMISOM. Reaching political settlement becomes a pipedream.

Training of military and civilian personnel of the mission is based on the guidelines prepared by the AU Commission. Member states who contribute contingents to the sub-regional force are expected to harmonise the training of designated force with standards that are provided at continental and sub-regional levels. All the designated training centres are required to follow the standard of training procedures developed by the AU Commission in training the contingents.

The standard training guidelines include training in doctrine and in humanitarian law and international human rights law for the civilian and military personnel of the troops. In this regard it is worth pointing out that even though the aim of military intervention is not war per se, it is most likely to happen in a combat situation. The military forces are bound by the rules of international humanitarian law. Even though AMISOM forces are not "State" forces in the strict sense of the word, their involvement inside a member state of the AU is governed by the rules applicable to international armed conflicts because the AMISOM forces are considered to be third parties inside a state. The forces are bound by the obligations under the 1907 Hague Regulations and the Fourth Geneva Convention. The obligations include the respect for the sovereignty of the occupied territory, the duty to restore and ensure public order, the duty to limit the occupation and the duty to allow access to international humanitarian organizations.

Training on new equipment should be done at own country before leaving. Effectiveness of peace enforcement team is enhanced if they understand their weapons well. Interoperability of equipment is vital. Contingents within the neighbouring boundaries should ensure compatibility of equipment. Communication equipment should be able to interlink with flanking friendly forces. Training on protection of children and civilians should top the list. Some soldiers were accused of sexual exploitation which indeed is a criminal offence. Sexual exploitation and abuse is strictly forbidden by the AU's code of conduct. Such crimes taint the good name of mission and prove to be counterproductive in the end. Punitive measures ought to be taken against such culprits. Protection of vulnerable population is key in any peace support operations. Even at the mission area such refresher courses should be run. Training should emphasize much on irregular warfare. In fight against insurgency, the battlefield remains fluid with no definite targets. Soldiers should be prepared to deal with such scenarios. It presents more challenges especially if one has to perform the duties of protection of civilians.

The Somalia National Army (SNA) is not yet prepared to conduct operations on its own. AMISOM cannot talk of exit strategy if the national security mechanism is not able to maintain security of Somalia after the peace enforcers pull out. SNA is still a weak force. A lot of mentoring should be offered. Capacity building is lacking within their ranks. Currently AMISOM is providing non-lethal support to the SNA it should be noted that without proper training, it's impossible 
to instill soldier discipline within them. There are in-fighting amongst the SNA and it normally takes clan inclinations. Political will has to be provided by the Federal Government of Somalia (FGS).

Biometric registration should be conducted and then positive vetting to be carried out. The exercise will help in weeding out the elements of $\mathrm{Al}$ shabaab within the ranks of SNA. As observed by an informant that training of the SNA lacks the necessary infrastructure. One has personnel to train but there are no resources. The soldiers have not been paid even a small stipend of $\$ 200$ to sustain their families while at the training camp. They have neither been registered nor vetted and that means that one could be training an Al shabab without their knowledge. No proper kitting for them. Morale boosting is prudent when undergoing training. Such challenges make training the SNA very hard. Most of them desert and leave training half-way or come for the training when they feel like. Indeed Somalia National Security Forces (SNSF) lack institutional, logistical and operational capabilities and are unable to fully integrate into AMISOM operations. Objectives of training cannot be achieved. Demobilization, disarmament, and reintegration (DDR) enhances the effectiveness of SNA. SNA is a conglomerate of many militia groups including clan militia and remnants of the former SNA. To harmonise their operations, common doctrine for training should be adopted for reasons of unity. However, training is carried haphazardly by different donors; the training packages are not synchronized. Every donor wants to train based on their doctrines thus creating a lot of confusion. This calls for one established recruit training school where they can be trained based on a common doctrine. This will enhance the efficiency of AMISOM operations and consolidate security gains across Somalia.

Training should cover comprehensive approach for the gains of peace support operations to be realized. Peace building and post-conflict reconstruction are ingredients of moving Somalia closer to being a self-governing state. AMISOM cannot stay in Somalia forever. There is need to undertake a review of immediate requirements for AMISOM and SNA operational effectiveness with a view to implementing remedial actions aimed at improving offensive operations against Al Shaabab and directs UNSOS to provide the identified support requirements as agreed with AMISOM and SNSF leadership. With the dwindling funds from the major donors and friends of AMISOM, the fate of Somalia hangs on a thin balance. Soldiers arriving at the mission areas should be aware of their roles.

\subsection{Funding}

The heart of humanitarian and peace support operations lies in the ability to conduct operational logistics to sustain the assigned forces. The sub-region's austere environment presents difficult logistic challenges. Limited transportation infrastructure requires that airlift be present to augment ground and sea transportation assets in response to crises and conflict situations. AMISOM has near to non-airlift capability thus will have to rely on external assistance for deployment and sustainment of the forces. The problem of logistics is not only that of 
outdated communication and operational equipment but also the ability of the force to maintain modern logistical infrastructure and supply system. This points to funding of the mission. AMISOM needs support from the international community as well as that of UN. Failure of enough funding will hinder peace support operation from achieving the intended strategic objectives. Under its concept of operations a lot of resources are needed for efficacy (an informant).

The AMISOM troops might have to concentrate more on airstrikes to cut down on expenses this will cut down the expenditure in the fight against the armed militia group. The major donor European Union (EU) announced their plan to reduce on their funding. EU said the reduction on the funding is due to financial constraints. AU officials were prompted to meet in order to discuss how they could reduce on the budgeting to avoid, "waste and duplication", of functions in Somalia. The partners included representatives from the EU, the UK, France, the US, China and the United Nations.

AMISOM strategic objectives will remain a dream. The budget cut is likely to affect operations. AMISOM should try to promote resource optimisation, greater coordination and avoid duplication of efforts. AU should recommend alternative financing for the mission. These other sources of funding are meant to fill the gap. The African Peace Facility (APF) should be able to sustain the mission through the assessed contributions from the union members. However most of the members fail to pay their contributions neither do they meet their pledges. APF was established in 2003 to respond to African request to support its peace and security agenda and has been involved in other parts of Africa such as Central African Republic, South Sudan, Somalia and the Comoros. It (reduction in funding) is caused by the financial constraints on the EU African Peace Facility which funds AMISOM and reflects the huge demands placed upon it to support African peace and security efforts.

Supporting AMISOM operations requires astronomical figures of dollars. The Somalia mission meant to stabilise the government in Mogadishu and fight extremists has received $€ 1.1$ billion covering allowances for the 22,000 troops, pay for the police component, international and local civilian staff as well as operational costs of the mission's civilian office in Nairobi. For example, since 2007 to the end 2015, EU provided $€ 1.1$ billion (Sh123.2 billion) to AMISOM and this has depleted funding. From January 2016, the EU reduced financial contribution to AMISOM by 20 per cent. It means that the EU will give $€ 20$ million (Sh224 million) every month up to June. AMISOM requires about $\$ 300$ million (Sh30 billion) a month. Its soldiers are paid a mission allowance of $\$ 1,028$ (Sh103,828) a month with no other allowances. For a KDF soldier, the government deducts an administration fee of $\$ 200$ (Sh20,200), meaning every serviceman gets $\$ 828$ (Sh83,628). This cut will not augur well with the soldiers taking into consideration of risk in the pacification of Somalia.

\subsection{Command and Control}

The command and control mechanisms are inadequate forcing the troops to act 
in a disjointed manner. The Kenyan air and maritime assets were not incorporated in AMISOM. These despite the AMISOM rehatting the KDF units with the "Green helmets". KDF transited from the Operation Linda Nchi into AMISOM operations. The Kenyan warships and jet fighters operate at the cost of taxpayer's expenses. As recited by one informant that during the amphibious operation in which KDF captured the port of Kismayu and the subsequent fall of the town, the waships provide naval gun support. Also ferrying of troops and equipment. All the assets provided by TCCs should be under command of AMISOM. Equipment package plan should cover such equipment.

Djibouti meeting stressed the need for effective AMISOM command and control in order to achieve synergy of the Mission's efforts against Al shaabab and therefore directs AMISOM contingents to fully support the Force Commander in his exercise of effective and accountable command of all Military units and equipment assigned to the Mission, under the overall leadership of the Special Representative of the Chairperson of the AU Commission and AMISOM Head of Mission.

The command structure is likely to be influenced by external forces. This is due to the fact that the troops are not fully under the command of the AMISOM. The troop contributing country still dictates where her troops are to be deployed within AMISOM.

The AMISOM command is overstretched thus making its control complicated. Most of the military bases are kilometres apart. Reaction time to beef up such areas takes relatively long. To reduce the long stretches, AU, UN and the international community should agitate for more troops. These troops will interlink the uncovered gaps. Al shabaab is maximizing on the AMISOM weakness by dominating these space with patrols. In turn they launch ambushes and IED attacks at their own conveniences. Alternatively, these unmanned spaces can be dominated by armed air patrols. The aircrafts should be fitted with ground to air communications to prevent friendly fire and effective coordination. The area of operation for a fighting company presently ought to be covered by a battalion thus making AMISOM less operational.

Suspicion amongst the TCCs is still high. Unity of effort cannot be realized if the contingents are suspicious of one another. It jeopardizes operations. There is lack of sharing of information which could have helped in planning. One respondent noted that it is as if the troop contributing countries are in a kind of competition. Yet their efforts should have a bearing and reflection of the good of the Somali community. Each country is apparently serving her national interests. There is no well-established contacts point where liaison could be done with flanking friendly forces. That explains why an outpost was overrun in Gedo region and there were no rescue effort for nearly five days. With a strong command and control, reinforcement should have been sent to secure the distressed soldiers at El-Adde.

\subsection{Emerging Threats}

Increasingly, AMISOM is being called upon to deal with emerging security challenges for example, those pertaining to maritime security including piracy, dump- 
ing of toxic wastes, over-fishing among others along the coast of Somalia. These tasks require resources. The stretch of coastline need coast guards manning. Such actualities must be addressed by the AMISOM so that capacity building can be enhanced (Informant).

The slow pace in liberating areas occupied by Al-Shabaab and the sporadic attacks in the liberated areas can lead to anxiety among the Somali population. Indeed, the Somali government, which is receiving support from AMISOM, could face credibility deficit whereby legitimacy of government is questioned and the resulting vacuum could easily be retaken by Al-Shabaab. These are realities the AMISOM has to contend with.

\subsection{Clan Enmity}

The Somali people are among the most homogenous in Africa, both ethnically and religiously. However they are deeply divided by an ancient family or clan system which stands at the foundation of political and social life.

Somalia has five main clans and numerous sub-clans in the population structure of Somalia. The Hawiye clan is most closely associated with the Islamic extremists and represents some $25 \%$ of the population. Traditionally, it is located in the areas north of Mogadishu and stops below Punt land. Northwest Somaliland and eastern Ethiopia is the territory of the Isaaq clan, a tribe representing $22 \%$ of Somalia's people. The Darod clan is the most widely distributed tribal network and accounts for some $20 \%$ of the Somali population. It covers Puntland and a little further south, as well as the area bordering Kenya.

\subsection{Fighting Strength of the Troops}

A key challenge especially in regards to the military component of AMISOM is the insufficient number of troops necessary to guarantee the stabilization of areas liberated from Al-Shabaab and to continue with military offensive to root out all insurgency in the country. These areas are expansive thus they need more battalions to man them (Respondent). AU should actually appeal to the member states to contribute more troops for the success of the mission. Indeed, the increase of troop levels from 12,000 to 17,731 through Security Council Resolution 2036 had significant impact on the military operations. However, this number is still too low to stabilize whole of Somalia given its size and the asymmetric nature of threats posed by Al-Shabaab. In a letter to the president of the UN Security Council sent in October 2013, it is noted that there was need to increase the capability of AMISOM to enable it, operating alongside the Somali forces, to liberate and secure territory in Somalia and to effectively deny Al-Shabaab the opportunity to mobilize resources and/or forcefully recruit and train insurgents to prosecute its asymmetric warfare.

\subsection{Weak Federal Government of Somalia}

Somalia has a weak government which needs a lot of mentoring before it can operate independently on its own. The Somali leadership needs to support the 
AMISOM stabilization efforts if substantial gains are to be made. An informant said, "some of the leaders are a little bit slow in implementing the proposed policies and as such are slowing down the whole process".

Political in-fighting for dominance of clan should be resolved. Clan dynamics fuels conflict and is further exploited by $\mathrm{Al}$ shabaab. The armed group continues to blow off the civilians within hotels, beaches and even at the airport; it discredits the government which is incapable of providing security to its people. UN and the international community should come together to help in sustaining peace support operations on Somalia. Peace and security in the face of transnational terrorism remains a collective responsibility. Command and control should not be sanctioned by the TCCs other than by FHQs. The uncoordinated operations cannot create synergy needed to contribute to the desired end state. The next chapter discusses summary, conclusion and recommendations of the study.

\section{Conclusions}

In evaluation of the challenges AMISOM faces in influencing peace building strategies in Somalia, the study concluded that the mission needs some special support to increase efficiency of its operations. AU should ensure sufficient funds for the operations otherwise the lives of troops lost in the pursuit of peace in Somalia means and remain nothing. It should adopt a sustainable source of funding. Apparently, it seems that the international community is losing interest of conflict in Somalia. With the cut of funding by EU, UN should have chipped in to cover up the gap, however, that is yet happen.

Support of the mandate remains big challenge to AMISOM. The mandate is overwhelming and thus requires robust resources. Stabilization of Somalia requires commitment from all stakeholders. If not checked properly, it could become one of the most expensive peace support operations which only consume both human resource and materiel. It is likely to become lucrative deal for generals and a source of diplomatic capital for presidents. Though not there yet, it looks like that AMISOM is headed to where the UN Stabilisation Mission in the Democratic Republic of the Congo, MONUSCO, is now [14]. It is the largest and most expensive UN peacekeeping mission in the world, but also, according to its critics, it's most ineffectual and corrupt. It has become such a gravy train for the UN mafia, reports speak of militias pillaging villages across the road from a MONUSCO camp while the Pakistani and Bangladeshi troops remain holed up in their base watching cricket via satellite $T V$.

\section{Recommendations}

The study recommends that AMISOM should look for sustainable sources of funding so that its operations are not hampered by donor dependency realities. AU should look for a sustainable source of funding for the mission. It should not rely on UN, donors (EU) and "friends of AMISOM" for financing these operations. Troops lack adequate modern equipment and there is high civilian turn 
over due to insufficient funds. AU should establish a peace fund kitty where members should make assessed contributions.

Somalia needs unified international support. The UN and the international community should rally behind AMISOM. Peace strategies have to be supported for success. Somalis who are willing to negotiate to help end conflict in Somalia should be involved. Common strategies will be necessary if the international community is to fight the outlawed groups in Somalia. The international community should be committed to supporting peace initiatives from locals at any time.

Capacity building for the SNA and police force should be developed as part of the exit strategy. They should undergo the necessary training as well as mentorship so that they can take over the security sector. In line with its Strategic Concept, the Police component of AMISOM should continue to build on its Formed Police Units (FPUs) in order to be more effective in public order management. In addition, AMISOM should enhance its support to the Somali Police Force and facilitate its transformation into a credible law enforcement component.

The troops require necessary training before being deployed in any peace support operations. They should be equipped with required weapons and machines to allow efficient operations. The contemporary insurgents are well trained and adequately equipped. The fight mode of the troops during engagements with the militants can be curbed through confidence building. The troops should be able to have faith in themselves as well as their weapons. They must have the will and resolve to fight. This will help in ending the hostilities. The mission should also consider engaging the armed groups in peace talks if need be.

\section{References}

[1] Hesse, B. (2014) Two Generations, Two Interventions in One of the World's Most-Failed States: The United States, Kenya and Ethiopia in Somalia. Journal of Asian and African Studies, 1, 1-28

[2] Mukhtar, M.H. (2003) Historical Dictionary of Somalia. Scarecrow Press, Lanham and Oxford.

[3] Lister, T. (2013) Ruthless Leader Aims to Extend Reach of Al-Shabaab, Eyes the West. http://www.cnn.com/2013/10/06/world/africa/al-shabaab-leader/

[4] United Nations Office for the Coordination of Humanitarian Affairs (2008) Somalia: Suicide Bombers Strike Bosaso, Hargeisa, Killing Dozens.

http://www.irinnews.org/report/81175/somalia-suicide-bombers-strike-bossaso-har geisa-killing-dozens

[5] Pflanz, M. (2009) Al-Shabaab Blamed for Somalia Bombing-Is Al-Qaeda's Influence Rising?

http://www.csmonitor.com/World/Africa/2009/1203/p06s13-woaf.html

[6] Mohamed, M. (2015) Somalia Blast: Mogadishu Hotel Rocked by Bomb. http://www.bbc.com/news/world-africa-33669610

[7] Omar, A. (2016) War and Conflict. Daily Nation Newspaper, Nairobi.

[8] Jeremy, S. (2012) Dirty Wars: The World Is a Battlefield. Sage, London.

[9] Williams, P.D. (2012) The Peace and Security Council of the African Union: Eva- 
luating an Embryonic International Institution. Journal of Modern African Studies, 47, 603-620. https://doi.org/10.1017/S0022278X09990048

[10] Djibouti Declaration (2016) Summit of Troop and Police Contributing Countries of AMISOM.

[11] Chalk, P. (2005) The Maritime Dimension of International Security, Terrorism, Piracy and Challenges for the United States. California: Research and Development (RAND).

[12] Dagne, T. (2009) Somalia: Prospects for a Lasting Peace. Mediterranean Quarterly, 20, 95-112. https://doi.org/10.1215/10474552-2009-007

[13] Lloyd, R. (2009) What Is Piracy? Thoughts from the Human Rights in Africa Conference. Peace and Justice News. http://www.pjcvt.org/M-ay\%202009.pdf

[14] Wilklund, C. (2015) AMISOM, A Model for Peace Support Operation in Mali. African Security, 45, 40-49.

Submit or recommend next manuscript to OALib Journal and we will provide best service for you:

- Publication frequency: Monthly

- 9 subject areas of science, technology and medicine

- Fair and rigorous peer-review system

- Fast publication process

- Article promotion in various social networking sites (LinkedIn, Facebook, Twitter, etc.)

- Maximum dissemination of your research work

Submit Your Paper Online: Click Here to Submit

Or Contact service@oalib.com 